\title{
JESZCZE JEDEN ŚWIAT
}

\section{Monika Gawlak, Świat poetycki Gregora Strnišy, Wydawnictwo Uniwersytetu Śląskiego, Katowice 2012, 200 s.}

W kręgu zainteresowań badawczych polskich slawistów znajdują się rozmaite zagadnienia, których opracowania należą do ważnych osiągnięć współczesnej slawistyki. W szczególności pragnę podkreślić publikacje poświęcone poezji, które powstawały w każdym większym ośrodku slawistycznym, m.in. na Uniwersytecie Śląskim. Artykuły i książki o poezji chorwackiej, serbskiej, słoweńskiej, macedońskiej, czeskiej i słowackiej, bułgarskiej czy łużyckiej stanowią znaczący dorobek slawistyki śląskiej. Nie zawsze są odnotowane przez recenzentów, co przy niewielkim zazwyczaj nakładzie publikacji ogranicza wiedzę i o publikacjach, i o ich przedmiocie. Jednym z ostatnich wydań, poświęconych poezji słoweńskiej, jest książka Świat poetycki Gregora Strnišy Moniki Gawlak. Autorka prezentuje nieznany w Polsce (lub bardzo słabo znany) świat wyobraźni dwudziestowiecznego poety słoweńskiego, którego twórczość należy do najwybitniejszych osiągnięć słoweńskiej literatury XX wieku. W obszernej monografii Monika Gawlak omawia główne komponenty poetyckiego świata Strnišy, wnikliwie analizując i interpretując wybrane problemy twórczej świadomości. Książka wprowadza w biografię słoweńskiego poety, w meandry rozwoju jego twórczości literackiej, w świat słowa własnego i słowa cudzego, którego mozaikowość urzeka poetycką energią i wiedzą. Autorce udało się pogodzić postawę kompetentnego literaturoznawcy, swobodnie poruszającego się po współczesnych teoriach i metodologiach z pełną pasji postawą zaangażowanej czytelniczki, która nie tylko rzetelnie wyjaśnia, ale i empatycznie rozumie sens przesłania poetyckiego słowa Strnišy.

By uzyskać klarowność wypowiedzi, prezentacje zostały podzielone na pięć wybranych zagadnień, poprzedzonych uwagami wstępnymi. 
We Wstępie przedstawiono pokrótce recepcję twórczości Strnišy, która została oceniona jako bardzo skromna. Strniša jest obecny na polskim rynku wydawniczym przede wszystkim dzięki Katarzynie Šalamun-Biedrzyckiej, zasłużonej tłumaczce i interpretatorce poezji słoweńskiej. Omówiono też słoweńską recepcję twórczości z wyakcentowaniem różnic interpretacyjnych, co pozwoliło autorce przejść do prezentacji własnych punktów widzenia, koncepcji całej pracy i kolejnych rozdziałów.

W rozdziale pierwszym Twórczość, życie i światopoglad Gregora Strnišy czytelnik poznaje słoweńskiego twórcę w perspektywie rozwoju słoweńskiej poezji powojennej, przynależności pokoleniowej, biografii oraz preferowanych tematów. W tym ogólnym i wprowadzającym rozdziale pojawia się kluczowe dla Strnišy pojęcie „kosmicznej świadomości”, które będzie powracać $\mathrm{w}$ dalszych częściach pracy. Tym samym otrzymujemy ważny sygnał, że pojęcie to jest dla słoweńskiego poety szczególnie ważne i w znacznej mierze będzie ono wyznaczać zainteresowania tego twórcy, a także determinować jego wyobraźnię czy kierunki myślenia. Pojęcie „kosmicznej świadomości” (kolidujące z jej słownikowymi definicjami) zostało wyeksponowane jako najważniejszy element światopoglądu i estetyki Strnišy, zasadnicza dla twórcy kategoria, umożliwiająca całościowy ogląd jego twórczości, a więc wgląd w sensy poetyckiej hipostazy kosmicznej świadomości czy też prywatnej, współczesnej epifanii, która wtajemnicza, lecz nie „objawia”. Podjęte w pierwszym rozdziale wątki są kontynuowane w rozdziale drugim Poetyckie stwarzanie świata. Akt twórczy jako dialog z idea kosmogonii oraz uzupełniane o problematykę ciała czującego, wpływu, wymiany, rozumiejącego dopełnienia, etyki geometrycznej. Pojawia się niezwykle ważny w literaturze, także w twórczości Strnišy, obraz człowieka jako istoty współodczuwającej i współrozumiejącej. Obraz ten eksponuje procesualność, w której nie ma miejsca na duchowość rozumianą jako powrót do pierwotnej natury, chodzi bowiem o nieustanną, ciągłą integrację natury i ducha, czyli świata (kosmosu) i człowieka (anthroposa). W tym kontekście współczesny antropocentryzm jawi się jako wynik zapomnienia „człowieka kosmicznego” i nadmiernej troski o człowieka nowożytnego racjonalizmu, ustanawiającego ludzką jednostkę autonomiczną i samoistną wartością.

Rozdział drugi omawia kategorię świadomości kosmicznej skonkretyzowaną w kreacjach poetyckich mitów stwarzania świata. Tomiki 
i poszczególne wiersze są ukazywane w pryzmacie wielostronnych korelacji idei „świadomości kosmicznej” i idei ,jedności bytu” z rozmaitymi płaszczyznami poetyckiego doświadczenia strukturyzującego kolejną kosmogonię, literacki mit stwórczy, testujący i reinterpretujący znaki języka i świadomości mitu, jego symbole i ich treści. Jest to ważny rozdział, wprowadzający nie tylko w sieć poznawanych sytuacji lirycznych, obrazów, znaczeń i sensów, ale także w centrum wyobraźni Strnišy, jego świadomości, preferowanych wartości, identyfikacji z rzeczywistością nie tylko mityczną. Rzeczywistość, w której przyszło żyć słoweńskiemu poecie, prowokowała do penetrowania różnych sytuacji poznawczych.

Autorka rozprawy stara się przede wszystkim poznać strukturę literackiego mitu Strnišy, odnaleźć jego źródła czy wzorce, określić sposoby kreowania rzeczywistości poetyckiej, transformowania chaosu w świat. Interesują ją zasady konstrukcji języka symbolicznego, jego znaki i zaszyfrowane w nim treści, a więc te wszystkie elementy, które są szczególnie istotne dla interpretacji poezji Strnišy w ogóle. Każdy byt w kosmosie-całości (poetyckiej kosmogonii) pełni swą cząstkową funkcję, jest współ-okiem świata, jest organicznym ciałem czującym, funkcją ciała kosmicznego, świadomości kosmicznej. Fantastyczny świat poetyckiej kosmogonii Strnišy jest światem dogłębnie tragicznym. Jego mieszkańcami są istoty słabe i ambiwalentne - wszystkie one partycypują w procesie tworzenia i życia, w magicznej całości obrazów, symboli, także w porządku mitu. Egzystencjalny tragizm tej poetyckiej kosmogonii autorka rozprawy wyjaśnia przede wszystkim przez konteksty filozoficzne, co jest uzasadnione obecnością wątków myśli egzystencjalnej oraz figur mitu i symboli.

Rozdziały trzeci Przestrzeń i transwersja oraz czwarty Między poezja a filozofia Gregora Strnišy uzupełniają interpretację doświadczenia poetycko-mitycznego o refleksję nad przestrzenią w ujęciu artystycznym, egzystencjalnym i filozoficznym. Ich celem jest opis przestrzeni pojawiających się w obrazach poetyckich (modelach świata), wyróżniających się specyficzną logiką i kompozycją. Rekonstruowane cechy przestrzenne oraz zachodzące między nimi relacje umożliwiają lepsze zrozumienie poetyckich kreacji Strnišy i jego dziwnej rzeczywistości, korespondującej z nadrzeczywistością, jej różnymi poziomami, sferami, fragmentami. Autorka pokazuje między innymi proces uwewnętrzniania przestrzeni przez podmiot, interferencje przestrzeni materialnej z psychiczną, symbolizacje 
przestrzeni i jej znaczenia, kulturowe uwarunkowania przestrzennego modelu Strnišy.

W rozdziale piątym Świat słowa cudzego. Intertekstualność w poezji Strnišy podjęty został bogaty kompleks problemów wynikających ze związków poezji Strnišy z innymi tekstami literatury, sztuki, kultury. Autorka wykazuje bardzo dobrą znajomość teorii intertekstualności, korzysta z rozległych źródeł na ten temat, przywołuje je, a nawet dość szeroko omawia, by następnie wyzyskać ciekawsze pomysły dla interpretacji poezji Strnišy w kluczu wpływów, podobieństw, zależności, zapożyczeń, dziedzictwa, dialogu, inspiracji, konceptualizacji. W ten sposób pokazuje inne wymiary idei całości, ciągłości, wspólnotowości czy szerszej świadomości. Prezentuje również dialogi Strnišy z innymi pisarzami lub ich dziełami czy ideami - słoweńskimi i obcymi. Między innymi ze Srečko Kosovelem, niezwykle ważnym poetą słoweńskiej tradycji literackiej, ważnym również w kontekście przewodniej idei świadomości kosmicznej, a nie tylko świadomości jako mozaiki czy sumy statycznych indywidualnych stanów świadomościowych, którym blisko do krytykowanego przez Strnišę humanizmu antropocentrycznego, dewaluującego element wspólnotowy na rzecz indywidualnego. Ostatnie dwa rozdziały dopełniają informacje historycznoliterackie, konieczne dla usytuowania twórczości słoweńskiego poety w dialogach z kulturą XX wieku, a Zakończenie podsumowuje główne tezy książki.

Zadanie przedstawienia bardzo trudnej i bardzo ciekawej poezji Gregora Strnišy zostało przez Monikę Gawlak zrealizowane znakomicie. Jej książka prezentuje poetę, jego generację, najważniejsze wyznaczniki światopoglądu i koncepcji ideowo-artystycznej. W części analitycznej skupia uwagę na strukturze poetyckiej kosmogonii, specyfice wykreowanej przestrzeni poetyckich światów i ich intertekstualnych powiązaniach, które determinują całość i osobność poezji i literackiego mitu Strnišy. 